A broad range of medical and surgical details of pediatric liver disease and liver transplantation

\title{
Concise Pediatric and Adolescent Hepatology
}

\section{Editor: Anil Dhawan}
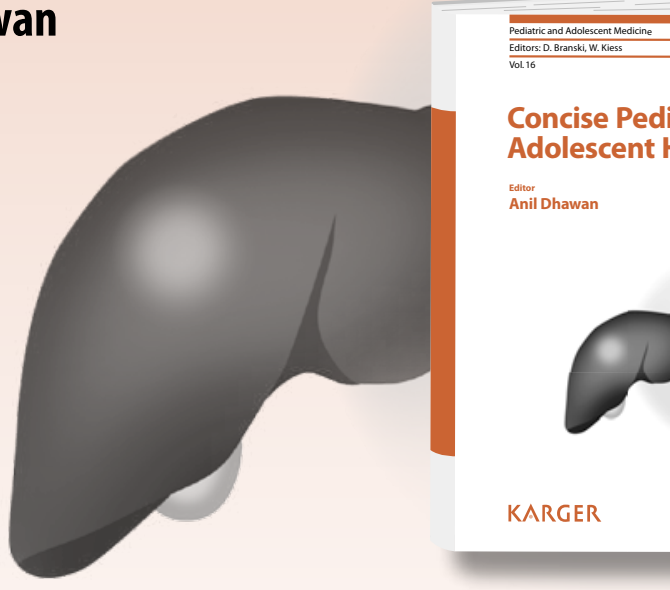

Concise Pediatric and Adolescent Hepatology

Eathor
Anil Dhawan

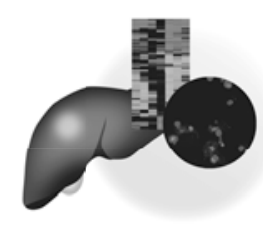

KARGER

Great progress in molecular biology, therapeutics, imaging as well as surgery have vastly improved the understanding and treatment of childhood liver disorders. In particular, surgical advancements in liver transplantation currently allow for a lower age or weight limit for recipients. Furthermore, the majority of children with liver disease or with liver transplantation today survive well into adulthood.

In this book, world experts in the now established subspecialty of pediatric hepatology provide a comprehensive summary of the latest advances in pathophysiology, molecular diagnostics and treatment strategies. Day-to-day management of liver transplant recipients as well as psychosocial aspects and complications during the challenging transition phase to adulthood are discussed in detail.

This up-to-date overview will be an invaluable tool for trainees in pediatric gastroenterology, a ready reference for busy clinicians and nurses or allied health professionals involved in the care of children with liver disease and after liver transplantation.

Pediatric and Adolescent Medicine, Vol. 16 Series Editors: Branski, D. (Jerusalem); Kiess, W. (Leipzig) ISSN 1017-5989

e-ISSN 1662-3886

\section{Concise Pediatric and Adolescent Hepatology}

Editor: Dhawan, Anil (London)

$X+264$ p., 36 fig., 6 in color, 34 tab., hard cover, 2012

CHF 198.- / EUR 165.- / USD 233.00

Prices subject to change

EUR price for Germany, USD price for USA only

ISBN 978-3-8055-9829-3

e-ISBN 978-3-8055-9830-9
Pediatrics; Gastroenterology; Hepatology,

Immunosuppression, Transplantation, Metabolic Disease, Intensive Care

www.karger.com/pamed

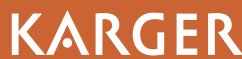

\section{CONTENTS}

\section{Preface}

Dhawan, A.

Growing Up with Liver Disease -

Psychological Aspects of Paediatric Liver

Disease

Boulton, H.; Bathgate, F.

Acute Liver Failure in Children and

Adolescents

Shanmugam, N.P.; Bansal, S.; Dhawan, A.

Progressive Familial Intrahepatic

Cholestasis in Children

Knisely, A.S.

Biliary Atresia

Hill, R.; Davenport, M.

Alagille Syndrome

Mouzaki, M.; Kamath, B.M.

Immune Deficiency-Related Liver Disease Hadzic, N.

Autoimmune Liver Disease

Mieli-Vergani, G.; Vergani, D.

Wilson Disease

Socha, P.

Non-Alcoholic Fatty Liver Disease in Children

Alisi, A.; De Vito, R.; Viggiano, D.; Morcaldi, L.;

Nobili, $V$.

Non-Cirrhotic Portal Hypertension

Yachha, S.K.; Jagadisan, B.

Primary Liver Malignancies Surgical Aspects Including Transplantation

Otte, J.-B.

Viral Hepatitis in Children

Stéphenne, X.; Sokal, E.

Non-Viral Infections of the Liver

Verma, A.

Intestinal Failure, Parenteral Nutrition and

Liver Disease

Goulet, 0.J.

Liver Transplantation

Ciria, R.; Heaton, N.

Hepatocyte Transplantation, 'Omics' and

Gene Therapy in the Management of

Liver Diseases

Jitraruch, S.; Qin, H.; Hughes, R.D.; Lehec, S.C.;

Mitry, R.R.

Author Index/Subject Index

www.karger.com/pamed 


\section{The Book Series}

A problem-oriented series for both the general practitioner and the hospital physician

\section{Pediatric and Adolescent Medicine}

\section{Series Editors}

Branski, D. (Jerusalem), Kiess, W. (Leipzig);

ISSN 1017-5989, e-ISSN 1662-3886

This series deals with rapidly evolving pediatric subspecialties such as perinatal medicine, pediatric endocrinology, immunology, neurology and cardiology. The individual volumes not only highlight recent advances in a particular area, but also provide a comprehensive overview of new trends in monitoring child development and subsequent adult health. The series aims to inform both the general practitioner and the hospital physician about current theoretical and practical developments in pediatric and adolescent medicine.

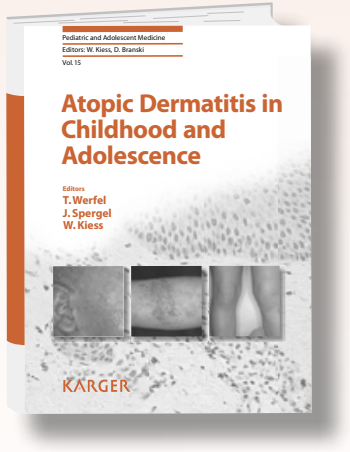

Vol. 15

Atopic Dermatitis in Childhood and Adolescence

Editors: Werfel, T. (Hannover); Kiess, W. (Leipzig); Spergel, J.M. (Philadelphia) VIII + 162 p., 14 fig., 8 in color, 18 tab., hard cover, 2011 CHF 164.- / EUR 137.- / USD 193.00 ISBN 978-3-8055-9570-4 e-ISBN 978-3-8055-9571-1

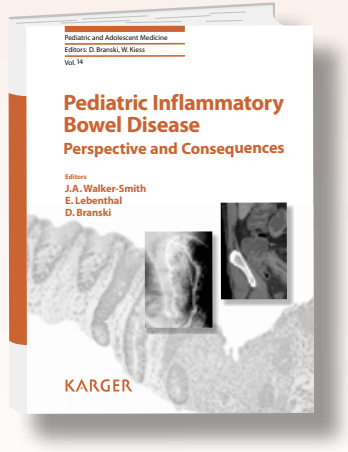

Vol. 14

Pediatric Inflammatory Bowel Disease: Perspective and Consequences

Editors: Walker-Smith, A.J. (London); Lebenthal, E.; Branski, D. (Jerusalem) $\mathrm{VIII}+204$ p., 51 fig., 24 in color,

14 tab., hard cover, 2009 CHF 178.- / EUR 148.- / USD 209.00 ISBN 978-3-8055-9134-8 e-ISBN 978-3-8055-9135-5

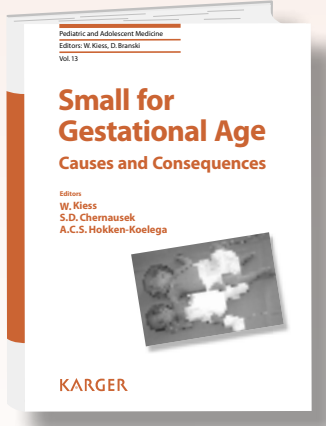

Vol. 13

Small for Gestational Age

Editors: Kiess, W. (Leipzig); Chernausek, S.D. (Oklahoma (ity, Okla.); Hokken-Koelega, A.C.S. (Rotterdam) VIII + 168 p., 23 fig., 7 in color,

17 tab., hard cover, 2009 CHF 158.- / EUR 132.- / USD 186.00 ISBN 978-3-8055-8657-3 e-ISBN 978-3-8055-8658-0

Prices subject to change EUR price for Germany, USD price for USA only

\section{Pediatric and Adolescent Medicine}

Please send

copy/ies: Vol. 16: Concise Pediatric and Adolescent Hepatology CHF 198.- / EUR 165.- / USD 233.00 ISBN 978-3-8055-9829-3

copy/ies: Vol. 15: Atopic Dermatitis in Childhood and Adolescence

CHF 164.- / EUR 137.- / USD 193.00

ISBN 978-3-8055-9570-4

copy/ies: Vol. 14: Pediatric Inflammatory Bowel Disease: Perspective and Consequences CHF 178.- / EUR 148.- / USD 209.00 ISBN 978-3-8055-9134-8

copy/ies: Vol. 13: Small for Gestational Age CHF 158.- / EUR 132.- / USD 186.00 ISBN 978-3-8055-8657-3

the book series Pediatric and Adolescent Medicine in continuation beginnig with vol.

All Karger series are available on continuation. Each volume will be sent upon publication until order is countermanded.

For easy ordering or information about other Karger publications log on to www.karger.com

Postage and handling free with prepayment

Payment

Please charge this order to my credit card

$\begin{array}{ll}\square \text { MasterCard } & \square \text { American Express } \\ \square \text { Visa } & \square \text { Diners }\end{array}$

Card No.:

Exp. date:

CVV/CVC:

(3 digits in the signature field on the back of Visa and MasterCard)

$\square$ Check enclosed $\square$ Please bill me

Name/Adress (please print):

Date:

Signature:

Orders can be placed at agencies, bookstores, directly with the publisher, or with any Karger distributor.

S. Karger AG, P.0. Box, 4009 Basel (Switzerland) Fax +41 6130612 34, E-Mail orders@karger.ch

USA: S. Karger Publishers, Inc., 26 West Avon Road, P.0. Box 529,

USA: S. Karger Publishers, Inc., 26 West Avon Road, P.0.
Unionville, CT 06085 (USA), Toll free: +1-800-828-5479

Germany: S. Karger GmbH, 79095 Freiburg

France: Librairie Médi-Sciences, 75007 Paris

Gulf Council Countries, Iran, Middle East, North Africa, Turkey:

Trans Middle East Internat. Distribution Co. Ltd., KaSha, Amman 11953 (Jordan) Japan: Karger Japan, Inc., Tokyo 105-0012

South East Asia, China and Taiwan: Karger Regional Office, Kuala Lumpur 50470 (Malaysia)

For details and further representatives and agencies see

www.karger.com/worldwide 